\title{
Structure and allergenicity assessments of bovine $\beta$-lactoglobulin treated by sonication-assisted irradiation
}

\author{
Fan Yang ${ }^{1,2}$ Li Zou, ${ }^{1,2}$ Yong Wu, ${ }^{1,2}$ Zhihua Wu, ${ }^{1,3}$ Anshu Yang, ${ }^{1,3}$ Hongbing Chen, ${ }^{1,3}$ and $\mathrm{Xin} \mathrm{Li}^{1,2 *}$ \\ ${ }^{1}$ State Key Laboratory of Food Science and Technology, Nanchang University, Nanchang 330047, China \\ ${ }^{2}$ School of Food Science and Technology, Nanchang University, Nanchang 330031, China \\ ${ }^{3}$ Jiangxi-OAl Joint Research Institute, Nanchang University, Nanchang 330047, China
}

\begin{abstract}
Bovine $\beta$-lactoglobulin ( $\beta$-LG) is recognized as a major allergen in milk. This study aimed to investigate ultrasound-assisted irradiation for reducing the allergenicity of $\beta-L G$, since irradiation can reduce the allergenicity of cow milk proteins and ultrasound can improve the quality of milk. The structural changes induced in high purity $\beta-\mathrm{LG}$, treated by irradiation, with or without sonication, were characterized by native PAGE, circular dichroism spectroscopy, and fluorescence spectroscopy. The changes in allergenicity were measured by IgE binding capacity to, and inflammatory mediator secretion by, human basophil KU812 cells. Surface hydrophobicity was reduced and aggregation of $\beta-\mathrm{LG}$ increased after treatment by irradiation, both with and without sonication. The $\operatorname{IgE}$ binding capacity and release of inflammatory mediators were reduced significantly and the reduction induced by irradiation before sonication was the greatest, suggesting that irradiation after sonication can be a safe and effective method to reduce the allergenicity of $\beta$-LG in dairy processing.
\end{abstract}

Key words: bovine $\beta$-lactoglobulin, irradiation, ultrasound, allergenicity

\section{INTRODUCTION}

Cow milk is widely consumed because of its richness in proteins, vitamins, and minerals (Macdonald et al., 2011). However, cow milk proteins can cause allergic reactions in infants and young children, who have immature gastrointestinal tracts and immune function. Epidemiological data show that the incidence of cow milk allergy is 5 to $15 \%$ in infants (Host, 2002), 0.6 to $2.5 \%$ in children and teens, and less than $0.5 \%$ in adults (Fiocchi et al., 2010). Most milk-protein allergy is trig-

Received June 5, 2019.

Accepted December 18, 2019.

*Corresponding author: zhizilixin@ncu.edu.cn gered by $\operatorname{IgE}$, which binds to high-affinity IgE receptor, expressed on the surface of mast cells or basophils and stimulates the release of inflammatory mediators, including histamine and cytokines. This leads to allergic symptoms, such as atopic dermatitis and bronchial asthma (Fujimura et al., 2002).

Food processing is used to improve the flavor and storage stability of foods, but can also increase the allergenicity of food proteins (Thomas et al., 2007). Thermal processing changes the protein structure and the conformation of the allergens by exposing or hiding the epitopes of the allergen, and may increase allergenicity (Rahaman et al., 2016; Teodorowicz et al., 2017). In contrast, nonthermal methods including irradiation (Lee et al., 2001; Meng et al., 2016), high hydrostatic pressure (Meng et al., 2017), enzymatic cross-linking (Stanic et al., 2010), and enzymatic hydrolysis (Knipping et al., 2012) usually reduce the allergenicity of cow milk proteins. Gamma irradiation is a useful technique in processing which can reduce the allergenicity of $\beta-\mathrm{LG}$ (Lee et al., 2001) and minimize the loss of sensory and nutritional quality in food (Kuan et al., 2013).

Sonication is widely used by the dairy industry, because it effectively inactivates enzymes, kills harmful microorganisms, homogenizes milk (Villamiel et al., 1999; Villamiel and de Jong, 2000), and improves the strength of gels made from milk protein concentrates (Kuo and Harper, 2003).

$\beta$-Lactoglobulin is one of the major allergens in cow milk, accounting for $50 \%$ of whey protein (Santos et al., 2012). Considerable progress has been made toward reducing the allergenicity of $\beta-\mathrm{LG}$ using irradiation. Oliveira et al. (2007) suggested that $\beta-L G$ could form ordered aggregates at gamma radiation doses up to 10 kGy. The structural modification of proteins induced by irradiation can destroy their antibody-binding epitopes (Byun et al., 2002). Ultrasound is a mild and safe process to improve the safety of foods, and $\beta-\mathrm{LG}$ treated with ultrasound was structurally modified to expose more hydrophobic surfaces than native $\beta-\mathrm{LG}$ (Stanic-Vucinic et al., 2012). We are not aware of any 
study on the effects of combining irradiation and ultrasound treatments on the structure of $\beta$-LG.

In this study, $\beta$-LG was treated with irradiation, with or without ultrasound and the structural changes characterized by circular dichroism (CD) spectrometry, fluorescence spectroscopy, and determination of free thiol content. Human basophilic KU812 was used to study the secretion of IgE/FceRI-related mediators, to evaluate changes in allergenicity.

\section{MATERIALS AND METHODS}

\section{Materials}

Fresh raw milk was collected from Jiangxi Sunshine Dairy Group Co. Ltd. (Nanchang, China). Iscove's modified Eagle's medium, fetal bovine serum, human myeloma $\operatorname{IgE}$, penicillin, and streptomycin were from Gibco BRL (Gaithersburg, MD). ELISA kits from Abcam (Cambridge, MA) were used to measure the levels of $\beta$-hexosaminidase $(\boldsymbol{\beta}$-HEX), tumor necrosis factor- $\alpha$ (TNF- $\boldsymbol{\alpha}$ ), and IL-6. Serum from 10 individuals with cow milk allergy and a positive skin prick test to cow milk was pooled. Specific IgE levels to $\beta-L G$ in the pooled serum were above $0.35 \mathrm{kU}_{\mathrm{A}} / \mathrm{L}$ (determined by Immuno CAP 100, Phadia AB, Uppsala, Sweden; Table 1). All other reagents were analytical grade, from local suppliers.

\section{Preparation and Characterization of $\beta-L G$}

Whey protein was extracted from fresh raw milk, as described previously (Li et al., 2008) and $\beta-\mathrm{LG}$ purified by preparative reversed-phase (RP) HPLC. A $20.0 \times$ $250 \mathrm{~mm}$ i.d. A SinoChrom ODS-AP, $300 \AA$ pore size, $100 \mu \mathrm{m}$ particle size column (Elite, Dalian, China) was used. The concentration and injection volume of whey protein were $8.06 \mathrm{mg} / \mathrm{mL}$ and $10 \mathrm{~mL}$, respectively, after the sample was filtered through a $0.45-\mu \mathrm{m}$ membrane.
Elution was performed at a flow rate of $10 \mathrm{~mL} / \mathrm{min}$, using a binary gradient of $0.1 \% \mathrm{vol} / \mathrm{vol}$ trifluoroacetic acid in water (A) and $0.1 \% \mathrm{vol} / \mathrm{vol}$ trifluoroacetic acid in acetonitrile (B). The percentage of solvent $\mathrm{B}$ was increased linearly from $30 \%$ at $0.01 \mathrm{~min}$, to $37 \%$ at $2 \mathrm{~min}$, $41 \%$ at $5 \mathrm{~min}$, held at $41 \%$ until $7 \mathrm{~min}$, increased to $45 \%$ at 9 min, held at $45 \%$ until 20 min then decreased back to $30 \%$ at $25 \mathrm{~min}$. The detection wavelength was set at $280 \mathrm{~nm}$. After 3 RP-HPLC purification runs, the $\beta$-LG concentration was determined by the Bradford method. Purity was estimated by SDS-PAGE. The gels were imaged with a GS-800 Densitometer (Bio-Rad, Hercules, CA). Quantity One 1-D analysis software (version 4.6.2; Bio-Rad Laboratories Inc., Hercules, CA)was used to quantify the electrophoresis bands.

\section{Irradiation and Ultrasound Treatments}

$\beta$-Lactoglobulin was dissolved in PBS (50 $\mathrm{m} M$, $\mathrm{pH}$ 6.8) to a concentration of $1 \mathrm{mg} / \mathrm{mL}$. Ultrasound treatment of $\beta$-LG samples was carried out at $28 \mathrm{kHz}$ and $300 \mathrm{~W}$ for $30 \mathrm{~min}$, using a Branson Sonifier 150 (Branson Ultrasonic Corp., Danbury, CT). The $\beta$-LG solution was cooled in ice to minimize heating during sonication. The samples were irradiated with a Co-60 irradiator (MDS Nordion, Kanata, ON, Canada) with a dose of $5 \mathrm{kGy}$, at ambient temperature. Four treatments were carried out: (A) untreated $\beta-\mathrm{LG}$ (N $\boldsymbol{\beta}-\mathbf{L G}$ ), (B) irradiated $\beta-\mathrm{LG}$ (I $\beta-\mathbf{L G})$, (C) $\beta-\mathrm{LG}$ sonicated then irradiated (U-I $\boldsymbol{\beta}-\mathbf{L} \mathbf{G}$ ), and (D) $\beta$-LG irradiated then sonicated (I-U $\boldsymbol{\beta}-\mathbf{L} \mathbf{G})$. After the treatment, the samples were characterized by native PAGE.

Native PAGE was carried out as described previously (Wittig et al., 2006) with some modifications. Briefly, protein samples were separated on $4 \%$ stacking gel and $15 \%$ separating gel, with a constant voltage of $60 \mathrm{~V}$ for $30 \mathrm{~min}$, then $80 \mathrm{~V}$ for $120 \mathrm{~min}$. Gels were imaged and quantified as for the SDS gels.

Table 1. Clinical data of 10 individuals with cow milk allergy

\begin{tabular}{llllc}
\hline Number & Sex & Age & Clinical symptoms & Specific IgE level $\left(\mathrm{kU} \mathrm{A}_{\mathrm{A}} / \mathrm{L}\right)^{1}$ \\
\hline 1 & Male & 2 yr old & Chronic cough & 0.44 \\
2 & Male & 10 mo old & Anaphylactic dermatitis & 2.48 \\
3 & Male & 2 yr old & Asthma & 0.62 \\
4 & Female & 11 mo old & Chronic urticaria & 0.93 \\
5 & Female & 1 yr old & UN ${ }^{2}$ & 0.87 \\
6 & Male & 11 mo old & UN & 10.1 \\
7 & Male & 4 yr old & Urticaria & 0.42 \\
8 & Male & 2 yr old & Anaphylactic rhinitis & 16.84 \\
9 & Male & 10 mo old & Anaphylactic purpura & 1.06 \\
10 & Male & 1 yr old & Urticaria & 3.42 \\
\hline
\end{tabular}

${ }^{1} \mathrm{kU}_{\mathrm{A}}=$ kilo units, $1 \mathrm{U}=2.4 \mathrm{ng}$.

${ }^{2} \mathrm{UN}=$ unknown. 


\section{Circular Dichroism Spectral Measurements}

The secondary structure of $\beta$-LG was determined by far-UV CD spectroscopy, using a Jasco J810 spectropolarimeter (Jasco, Gro-Umstadt, Germany). Briefly, all the samples were dissolved in PBS $(20 \mathrm{mM}$, pH 6.8) to $0.1 \mathrm{mg} / \mathrm{mL}$. The CD spectra were obtained by far-UV CD spectroscopy from 250 to $190 \mathrm{~nm}$, with a scan rate of $60 \mathrm{~nm} / \mathrm{min}$ and a bandwidth of $1.0 \mathrm{~nm}$, at room temperature. Each sample was measured 3 times. The secondary structure content was calculated using the CD website (http://dichroweb.cryst.bbk.ac.uk).

\section{Intrinsic Fluorescence and 1-Anilinonaphthalene-8- Sulfonate Fluorescence}

Fluorescence was measured at $25^{\circ} \mathrm{C}$ with an F-4500 Fluorescence Spectrophotometer (Hitachi, Tokyo, Japan) equipped with a 150-W Xenon lamp and a thermostatic bath. For intrinsic fluorescence measurements, the excitation wavelength was $280 \mathrm{~nm}$ and the emission wavelengths were from 300 to $450 \mathrm{~nm}$. For 1-anilinonaphthalene-8-sulfonate (ANS) fluorescence measurements, ANS solution $(30 \mu \mathrm{L}$ of $5 \mathrm{mM} ; 0.015 \mathrm{~g}$ of ANS in $50 \mathrm{mM}$ PBS, pH 7.4) was thoroughly mixed with protein sample $3.0 \mathrm{~mL}$ ), to give a final protein concentration of $0.1 \mathrm{mg} / \mathrm{mL}$. The optical path was $1 \mathrm{~cm}$ with a slit width of $2.0 \mathrm{~nm}$. Detection was conducted at $1,200 \mathrm{~nm} / \mathrm{min}$ with a 0.2 - to 0.5 -s response time and the fluorescence excitation spectrum was obtained at $375 \mathrm{~nm}$, with the emission wavelength from 400 to 650 $\mathrm{nm}$. Each sample was measured at least in triplicate.

\section{Determination of Free Disulfide Bonds by Ellman's Assay}

To determine the amount of total sulfhydryl $(\mathbf{S H})$ groups in the $\beta$-LG solutions, Ellman's reagent was employed (Iametti et al., 1998). Each sample was diluted into $1 \mathrm{mg} / \mathrm{mL}$ with $0.1 M$ balanced salt solution (86 $\mathrm{m} M$ Tris, $90 \mathrm{~m} M$ glycine, $4 \mathrm{~m} M$ EDTA in Milli-Q water, $\mathrm{pH}$ 8.0). Final solutions were made by mixing $5 \mathrm{~mL}$ of sample with $40 \mu \mathrm{L}$ of Ellman's reagent for 15 min at $25^{\circ} \mathrm{C}$ before measuring the absorbance at $412 \mathrm{~nm}\left(\mathrm{~A}_{412}\right)$ with a UV/VIS spectrophotometer (TU-1901 Lambda 25, Perkin Elmer, Singapore). Tris-Glycine buffer was used as the negative control. Free total SH groups were calculated as follows:

$$
\mathrm{SH}(\mu \mathrm{mol} / \mathrm{g})=73.53 \times \mathrm{A}_{412} \times \mathrm{D} / \mathrm{C},
$$

where C represented the sample concentration $(\mathrm{mg} /$ $\mathrm{mL}$ ) and $\mathrm{D}$ was the dilution ratio.

\section{Inhibition ELISA Analysis}

The IgE-binding ability of $\beta-L G$ was analyzed by inhibition ELISA with pooled serum from individuals with cow milk allergy, as described previously (Meng et al., 2017) with some modifications. Untreated $\beta$-LG $(2.5 \mu \mathrm{g} / \mathrm{mL})$ in carbonate buffer $(50 \mathrm{mM}$, pH 9.6) was coated in 96 -well plates $(100 \mu \mathrm{L} /$ well $)$ at $4^{\circ} \mathrm{C}$ overnight. Then, the plates were washed 3 times with PBS containing $0.05 \%$ Tween 20 . Each well was blocked with $3 \%$ gelatin in PBS for $1 \mathrm{~h}$ at $37^{\circ} \mathrm{C}$. Sera with a dilution of 1:30 mixed with inhibitors or PBS were added into another blocked plate and incubated for $1 \mathrm{~h}$ at $37^{\circ} \mathrm{C}$. The mixture of serum and inhibitors $(100 \mu \mathrm{L})$ was transferred to the plate coated with untreated $\beta$-LG, followed by incubation for $1 \mathrm{~h}$ at $37^{\circ} \mathrm{C}$. After washing, biotin-labeled anti-human IgE (diluted 1:5,000, 100 $\mu \mathrm{L}$ ) was added to the wells and incubated at $37^{\circ} \mathrm{C}$ for $1 \mathrm{~h}$. After washing again, the chromogenic substrate (100 $\mu \mathrm{L}, 3,3^{\prime}, 5,5^{\prime}$-tetramethylbenzidine) was added to the wells for $15 \mathrm{~min}$ incubation and the reaction terminated by adding $2 M$ sulfuric acid $(50 \mu \mathrm{L})$. Absorbance was measured at $450 \mathrm{~nm}$ with a Multimode Microplate Reader (Varioskan LUX 3020-Z034; Thermo Fisher Scientific, Waltham, MA).

\section{Culture of KU812 Cells}

The KU812 cells were obtained from the Chinese Academy of Sciences Cell Bank (Shanghai, China) and cultured in Iscove's modified Dulbecco's medium (IMDM) which contained $20 \%$ heat-inactivated fetal bovine serum, $2 \mathrm{mM}$ L-glutamine, $110 \mu \mathrm{g} / \mathrm{mL}$ sodium pyruvate, 100 units/mL penicillin $\mathrm{G}, 100 \mathrm{mg} / \mathrm{mL}$ streptomycin, and $10 \mathrm{~m} M$ HEPES buffer. The cells were cultured at $37^{\circ} \mathrm{C}$ in a humidified atmosphere with $5 \%$ $\mathrm{CO}_{2}$. When the cells reached to $10^{6}$ to $10^{8}$ cells $/ \mathrm{mL}$, they were used for further experiments.

\section{Release Assay for $\beta-H E X$, Histamine, IL-6, and TNF- $\alpha$}

The KU812 cells $\left(5 \times 10^{6}\right.$ cells $\left./ \mathrm{mL}\right)$ were washed with $1 \times$ PBS 3 times and incubated with $0.5 \mu \mathrm{g} / \mathrm{mL}$ Human Myeloma IgE (Merck Millipore, Darmstadt, Germany) at $37^{\circ} \mathrm{C}$ for 1 wk. Cells were collected by centrifugation and washed with the IMDM medium before incubation with $1 \mathrm{~mL}$ of IMDM containing pooled serum from milk-allergic individuals $(0.5 \mu \mathrm{g} / \mathrm{mL})$, overnight at $37^{\circ} \mathrm{C}$. The next day, the IgE-sensitized cells were incubated with $50 \mu \mathrm{g} / \mathrm{mL}$ processed $\beta-\mathrm{LG}$ or PBS (50 $\mathrm{m} M, \mathrm{pH} 6.8$ ), then the supernatant and cells were collected at different time points. To measure $\beta$-HEX release, the supernatant and cells were collected after 
$30 \mathrm{~min}$ of incubation and the cells were lysed for $30 \mathrm{~min}$ with $0.5 \%$ (vol/vol) Triton X-100 followed by centrifugation $\left(300 \times g\right.$ at $\left.25^{\circ} \mathrm{C}, 5 \mathrm{~min}\right)$ to obtain lysate. Equal volumes $(50 \mu \mathrm{L})$ of supernatant, lysate, and PBS were mixed with 4-nitrophenyl- $N$-acetyl- $\beta$-D-glucosaminide $(10 \mathrm{~m} M)$ in sodium citrate buffer $(0.1 \mathrm{M}, \mathrm{pH} 4.5)$ in a 96-well plate, followed by incubation for $1 \mathrm{~h}$ at $37^{\circ} \mathrm{C}$. The reaction was terminated with $200 \mu \mathrm{L}$ of $0.1 \mathrm{M}$ $\mathrm{Na}_{2} \mathrm{CO}_{3} / \mathrm{NaHCO}_{3}$ ( $\mathrm{pH}$ 11.0) on ice and for detection of $\beta$-HEX, and the optical density was measured at 405 nm.

Histamine release was measured by collecting the cell supernatant after 30 min of incubation and using an Enzyme Immunoassay Kit (Demeditec Diagnostics GmbH, Kiel, Germany), following the manufacturer's instructions. After $8 \mathrm{~h}$ incubation, the levels of IL- 6 and TNF- $\alpha$ were detected by the same method.

\section{Antigen Induced Intracellular $\mathrm{Ca}^{2+}$ Mobilization in KU812}

The $\mathrm{Ca}^{2+}$ was detected using $0.05 \%$ (vol/vol) Fluo-3 a.m. (Beyotime, Shanghai, China) working fluid diluted with Hanks' balanced salt solution, as reported previously (Shi et al., 2017). Briefly, KU812 cells in the logarithmic phase were incubated with human serum for $24 \mathrm{~h}$ and then were challenged with $50 \mu \mathrm{g} / \mathrm{mL}$ of $\beta$-LG sample at $37^{\circ} \mathrm{C}$. The cells were washed with Hanks' balanced salt solution 3 times, then incubated in $0.05 \%$ (vol/vol) Fluo-3 a.m. buffer at $37^{\circ} \mathrm{C}$ in the dark for 40 min, and fluorescence photographs were taken immediately using an inverted fluorescence microscope.

\section{Statistical Analysis}

All assays of every independent experiment were carried out in triplicate and the data difference was considered statistically significant at $P<0.05$. The results were expressed as mean values \pm standard deviation. Appropriate data were analyzed to determine statistical significance through one-way ANOVA (SPSS for Windows 2003, version 20.0, IBM Corp., Armonk, NY).

\section{RESULTS}

\section{$\beta-L G$ Purification}

A variety of methods have been used to obtain purified $\beta-\mathrm{LG}$, such as isoelectric precipitation (Bramaud et al., 1997; Gesan-Guiziou et al., 1999), ion-exchange and molecular-exclusion chromatography (Li et al., 2008), and RP-HPLC (Bonfatti et al., 2008). Reversed-phase HPLC is an effective way to analyze or prepare protein because it is characterized by good separations, short run-time, high accuracy, good repeatability, and reproducibility. The different components of whey protein were isolated by RP-HPLC (Figure 1). $\beta$-Lactoglobulin is a relatively hydrophobic protein and consisted mainly of subtypes $\mathrm{A}$ and $\mathrm{B}$ with similar properties. The proteins were collected from RP-HPLC (Figure 1A) and peaks 8 and 9 were identified to be $\beta$-LG by SDS-PAGE (Figure 1B). The average yield of $\beta-\mathrm{LG}$ was $32.25 \%$ from whey protein with a purity of $98.2 \%$ (Table 2). The faint band at about $36 \mathrm{kDa}$ is the $\beta$-LG dimer (Figure 1B).

\section{Molecular Weight Analysis}

Variants $\mathrm{A}$ and $\mathrm{B}$ of $\beta$-LG were observed around 18 $\mathrm{kDa}$ in native PAGE electrophoresis (Figure 1C), with a faint band of dimer also visible. Smearing visible between 36 and $170 \mathrm{Da}$ indicated the presence of aggregated $\beta-\mathrm{LG}$, formed during processing. Little difference was observed in the proportion of monomer and dimer after processing, apart from a small but significant increase $(P<0.05)$ in irradiated $\beta$-LG (Table 3 ).

\section{Detection of Secondary Structure Changes}

The secondary structural changes in $\beta$-LG induced by different treatments were determined by $\mathrm{CD}$ spectroscopy (Figure 2). The spectrum of untreated $\beta-\mathrm{LG}$ exhibited a slight positive peak at $196 \mathrm{~nm}$ and a strong negative peak at $216 \mathrm{~nm}$ (Figure 2A). However, the molar ellipticity of those peaks was higher than in a previous report (Meng et al., 2017), indicating a higher content of $\beta$-sheet in the secondary structures. Compared with untreated $\beta-\mathrm{LG}$, the negative molar ellipticity peak of the treated $\beta-\mathrm{LG}$ was decreased, whereas the positive molar ellipticity peak of U-I $\beta$-LG was mildly increased (Figure 2A). The distribution of secondary structures was calculated by the Jasco secondary structure software (Figure 2B). Random coil was the major structural type in untreated $\beta-\mathrm{LG}$, with very little $\beta$-sheet. The treatments all reduced the content of $\beta$-turn and random coil, converting them primarily to $\beta$-sheet in U-I $\beta$-LG, $\alpha$-helix in I-U $\beta$-LG, and a mixture in I $\beta$-LG. The increase in $\alpha$-helix in I-U $\beta$-LG was similar to the corresponding decrease in $\beta$-sheet, suggesting that they were interconverted by the treatment.

\section{Fluorescence Intensity and Free SH Group Contents of the Treated $\beta-L G$}

Conformational modification of $\beta$-LG by the treatments was characterized by fluorescence spectra and 
A

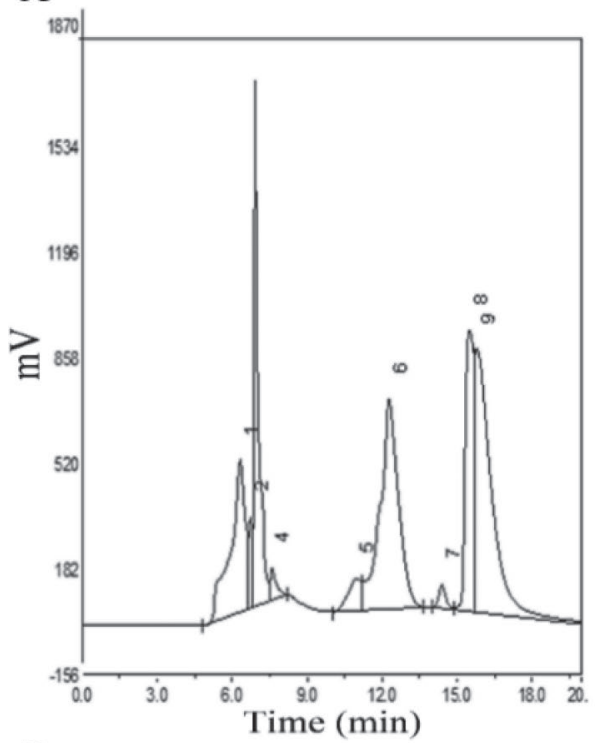

B

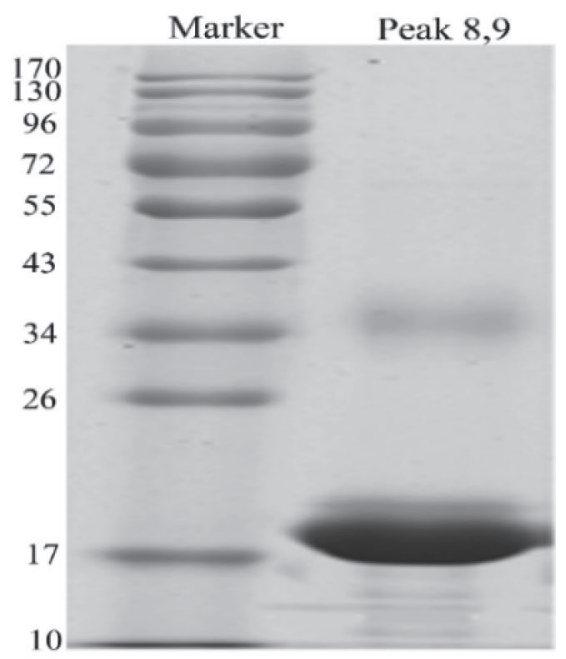

$\mathrm{C}$

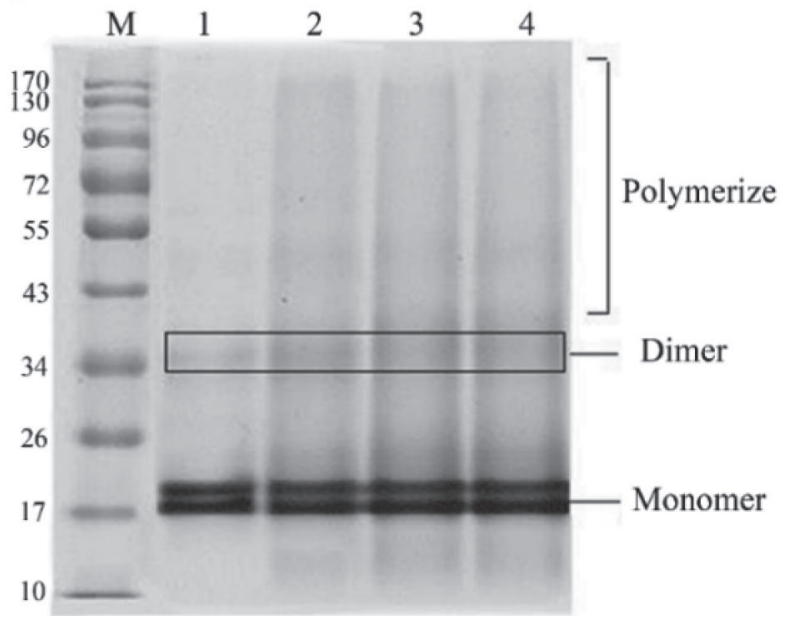

Figure 1. $\beta$-Lactoglobulin derived from preparative reversed-phase (RP) HPLC and treated by irradiation, ultrasound, or both. (A) Chromatogram of whey proteins from preparative RP-HPLC. (B) SDS-PAGE gel of purified $\beta$-LG. (C) Native-PAGE gel of $\beta$-LG treated with irradiation, ultrasound, or both. Lane M: pre-stained marker; lanes 1 to 4 , respectively: untreated $\beta$-LG, irradiated $\beta$-LG, $\beta$-LG sonicated then irradiated, and $\beta$-LG irradiated then sonicated.

quantification of surface SH groups (Figure 3). A lower fluorescence intensity of all the processed $\beta$-LG was observed, especially for I $\beta-\mathrm{LG}$, which decreased about

Table 2. Yield of $\beta$-LG from whey protein by preparative reversedphase HPLC

\begin{tabular}{lccc}
\hline & \multicolumn{3}{c}{ Run number } \\
\cline { 2 - 4 } Item & \multicolumn{1}{c}{1} & 2 & 3 \\
\hline Loaded protein (mg) & 80.6 & 80.6 & 80.6 \\
Purified $\beta$-LG isolated (mg) & 25.47 & 26.19 & 26.23 \\
Yield (\%) & 31.6 & 32.49 & 32.66 \\
Average yield & & $32.25 \pm 0.56$ \\
$(\% ;$ mean \pm SD) & & & \\
\hline
\end{tabular}

0.54-fold, and the decreases in the other 2 treatments were about 0.44 -fold (Figure $3 \mathrm{~A}$ ).

The intrinsic fluorescence spectra of the untreated $\beta-\mathrm{LG}$ had a maximum absorption around $333 \mathrm{~nm}$, with shifts in maximum absorption wavelength $\left(\boldsymbol{\lambda}_{\max }\right)$ values to $334 \mathrm{~nm}$ (red shift of $1 \mathrm{~nm}$; I $\beta-\mathrm{LG}$ ), $334 \mathrm{~nm}$ (red shift of $1 \mathrm{~nm}$; U-I $\beta-\mathrm{LG}$ ), and $335 \mathrm{~nm}$ (red shift of 2 $\mathrm{nm}$; I-U $\beta-\mathrm{LG}$ ), respectively. All these results indicated that about half of the aromatic AA were buried inside the protein structure.

The surface hydrophobicity of $\beta$-LG was determined using ANS, which binds to exposed hydrophobic residues on the surface of proteins for characterization of subtle conformational changes in protein structures 
Table 3. Proportion of monomer and dimer in $\beta$-LG treated by irradiation (I) and ultrasound (U) ${ }^{1}$

\begin{tabular}{lcccc}
\hline Item & Untreated $\beta-\mathrm{LG}$ & I $\beta$-LG & U-I $\beta$-LG & I-U $\beta$-LG \\
\hline Dimer (\%) & $6.96 \pm 0.21^{\mathrm{b}}$ & $8.75 \pm 0.07^{\mathrm{a}}$ & $7.55 \pm 0.07^{\mathrm{ab}}$ & $7.70 \pm 0.56^{\mathrm{ab}}$ \\
Monomer (\%) & $88.85 \pm 2.05$ & $83.11 \pm 4.94$ & $84.85 \pm 1.06$ & $86.50 \pm 1.56$ \\
\hline
\end{tabular}

${ }_{\mathrm{a}, \mathrm{b}}$ Mean values with different superscripts were significantly different $(P<0.05)$.

${ }^{1}$ Values are mean $\pm \mathrm{SD}(\mathrm{n}=3)$.

(Muresan et al., 2001). The ANS-fluorescence intensity spectrum of untreated $\beta-\mathrm{LG}$ had a maximum absorption around $475 \mathrm{~nm}$ (Figure 3B). Both U-I $\beta-\mathrm{LG}$ and I-U $\beta$-LG showed a slight red shift, whereas the $\lambda_{\max }$ value of I $\beta-L G$ was at $473 \mathrm{~nm}$ (red shift of $2 \mathrm{~nm}$ ), which suggested a more nonpolar environment. In addition, the ANS-fluorescence intensities in all the processed $\beta$-LG were significantly decreased, indicating that surface hydrophobicity was reduced and hydrophobic groups were buried inside the protein.

Disulfide bonds help maintain protein structural stability. The contents of total SH groups were increased in the 3 treated $\beta$-LG, compared with untreated $\beta-\mathrm{LG}$ (Figure 3C), indicating some breakage of disulfide bonds. Moreover, the SH contents in U-I treated $\beta-\mathrm{LG}$ and I-U treated $\beta-\mathrm{LG}$ were higher than that of I $\beta$-LG.

\section{Effect of Processing on IgE Binding Ability of Treated $\beta-L G$}

To assess the potential allergenicity, the $\operatorname{IgE}$ binding capacities of the untreated and treated $\beta-\mathrm{LG}$ were measured by an indirect competitive-inhibition ELISA with serum from individuals allergic to cow milk. The half-maximal inhibitory concentration $\left(\mathbf{I C}_{50}\right)$ value was lowest $(6.99 \mu \mathrm{g} / \mathrm{mL})$ for untreated $\beta-\mathrm{LG}$ (Figure 4). The $\mathrm{IC}_{50}$ values of I $\beta$-LG $(67.94 \mu \mathrm{g} / \mathrm{mL})$, U-I $\beta$-LG $(59.60 \mu \mathrm{g} / \mathrm{mL})$, and I-U $\beta-\mathrm{LG}(27.31 \mu \mathrm{g} / \mathrm{mL})$ were $9.72,8.52$, and 3.90 times higher, respectively, than untreated $\beta$-LG. All the treatments caused a large and significant decrease in the specific IgE binding capacity of $\beta-\mathrm{LG}$, and irradiation treatment was the most effective.

\section{A}

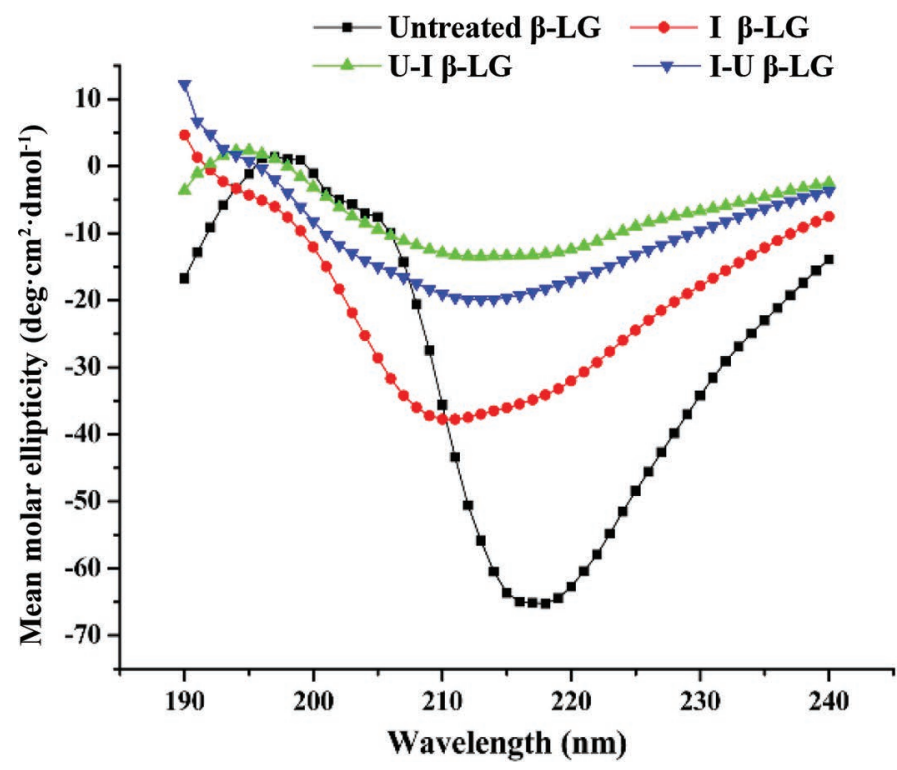

B

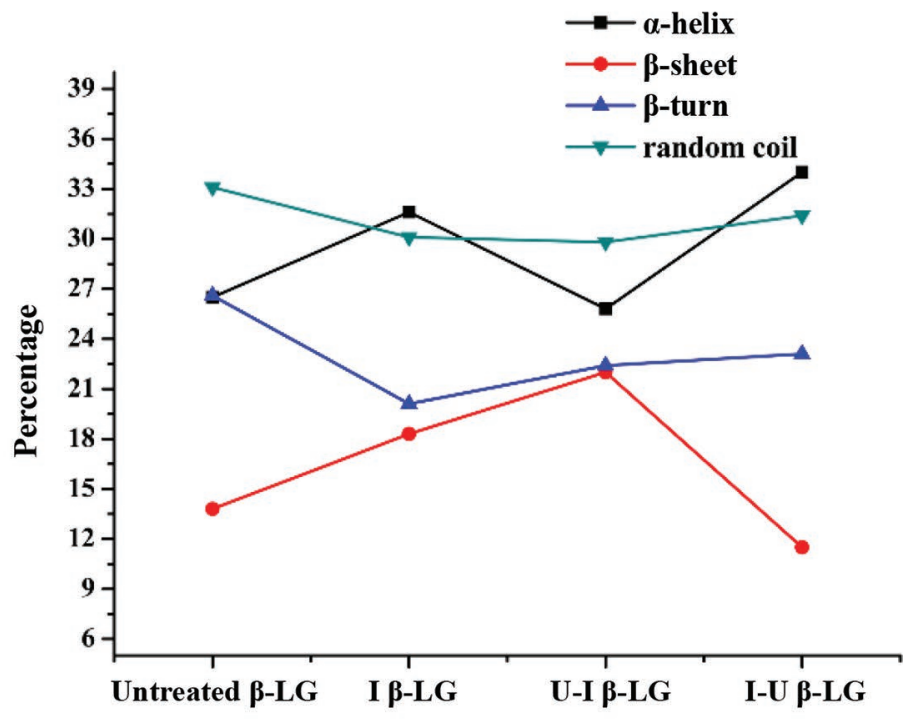

Figure 2. Secondary structure changes in $\beta$-LG measured by far-UV circular dichroism (CD) spectroscopy. (A) The CD spectra were recorded in the far-UV range $\left(190\right.$ to $250 \mathrm{~nm}$ ). All the measurements were done at $25^{\circ} \mathrm{C}$ and the sample concentration was $0.1 \mathrm{mg} / \mathrm{mL}$. (B) Secondary structure contents of the untreated and treated $\beta$-LG. I $\beta$-LG $=$ irradiated $\beta$-LG; U-I $\beta$-LG $=\beta$-LG sonicated then irradiated; I-U $\beta-\mathrm{LG}=\beta-\mathrm{LG}$ irradiated then sonicated. 
A

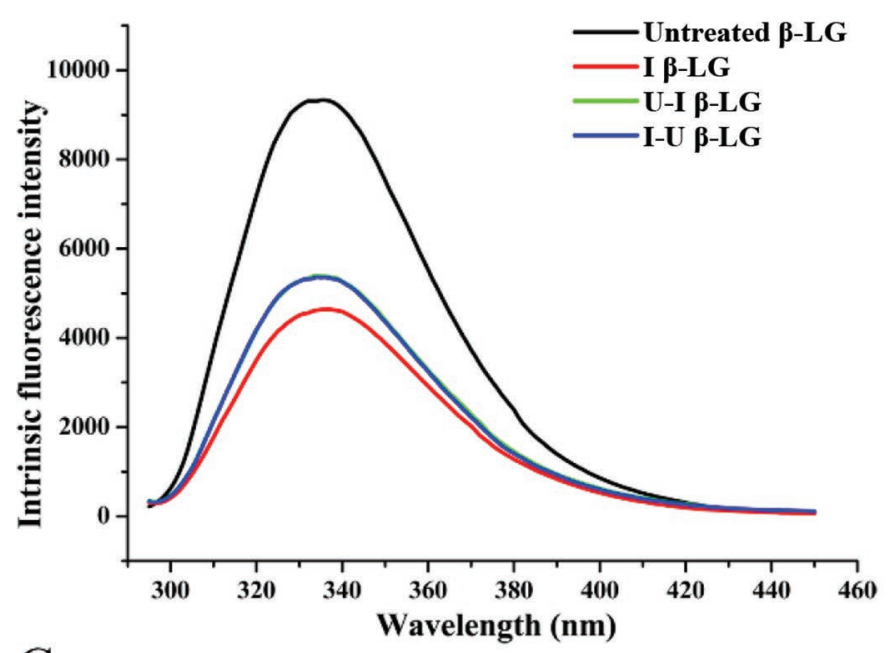

$\mathrm{C}$

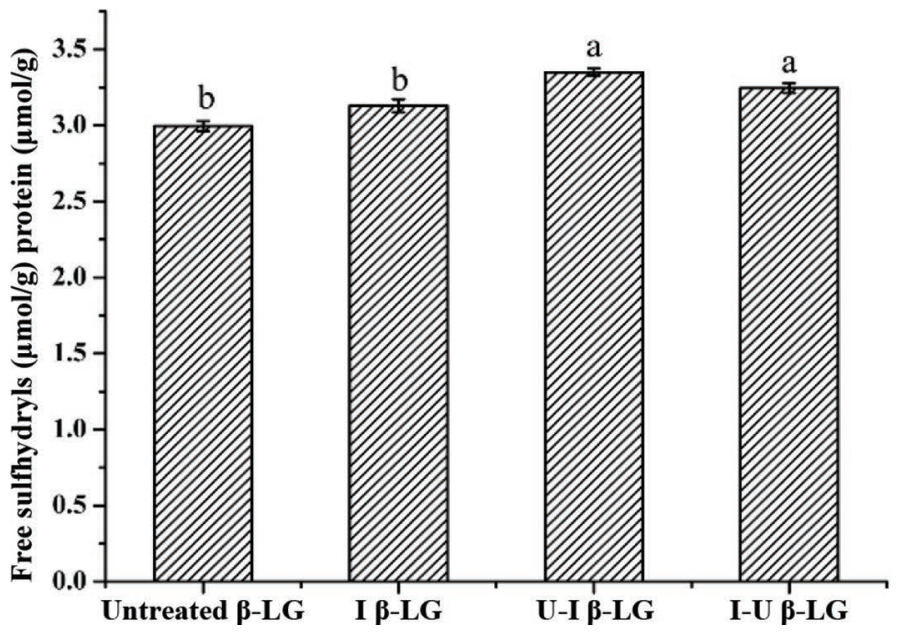

$\mathrm{B}$

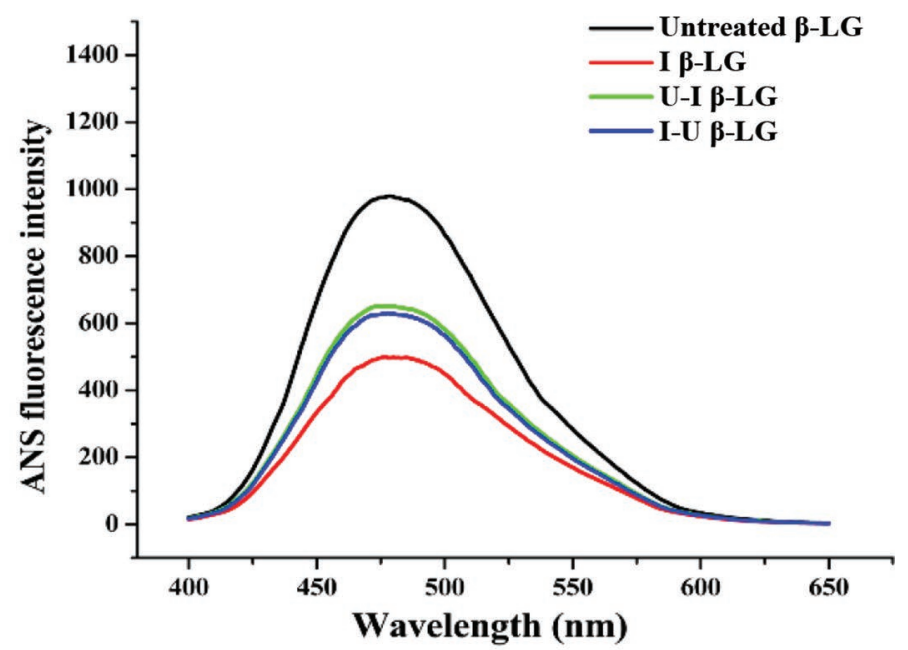

Figure 3. Fluorescence intensity and free sulfhydryl ( $\mathrm{SH}$ ) group content of $\beta$-LG with different treatments. Intrinsic fluorescence (A; spectra of U-I $\beta$-LG and I-U $\beta$-LG overlap) and 1-anilinonaphthalene-8-sulfonate (ANS) fluorescence (B) of untreated and treated $\beta$-LG. (C) Free SH group content of $\beta-\mathrm{LG}$. Data are represented as mean $\pm \mathrm{SD}(\mathrm{n}=3)$. Columns marked (a) were significantly higher in free $\mathrm{SH}$ groups $(P<0.05)$ than untreated $\beta$-LG and those marked (b) were not significantly different $(P>0.05)$. I $\beta$-LG = irradiated $\beta$-LG; U-I $\beta$-LG $=\beta$-LG sonicated then irradiated; I-U $\beta$-LG $=\beta$-LG irradiated then sonicated.

\section{Effect of Food Processing on Mediator- Releasing Capacity}

Human basophil KU812 cells were stimulated with $\beta$-LG to induce the secretion of the inflammatory mediators, $\beta$-HEX, histamine, TNF- $\alpha$, and IL-6 (Figure $5)$.

$\beta$-Hexosaminidase is a common biomarker for the KU812 degranulation response and only exists in the serum of $\beta$-LG-allergic individuals. The $\beta$-HEX secretion induced by the processed $\beta-\mathrm{LG}$ was about half that induced by untreated $\beta-\mathrm{LG}$ (Figure 5A; $P<0.05$ ), indicating that irradiation and ultrasound treatment could suppress $\beta$-HEX release from KU812 cells. Histamine is another important biomarker of basophil degranulation. The relative levels of histamine secreted in untreated $\beta$-LG, I $\beta$-LG, U-I $\beta$-LG, and I-U $\beta$-LG were $82.0,45.1,52.3$, and $54.5 \%$, respectively (Figure $5 \mathrm{~B}$ ). The histamine released in the 3 treated $\beta$-LG decreased by $36.9,29.7$, and $27.6 \%$, respectively. The 3 treated groups showed a dramatic difference from the untreated $\beta$-LG in promoting the release of histamine. The I $\beta-L G$ induced the lowest histamine release (Figure $5 \mathrm{~B} ; P<0.05)$. These results suggested that irradiation and ultrasound treatments could inhibit IgE-induced anaphylactic reactions by blocking the release of the 
pre-synthesized mediators $\beta$-HEX and histamine from KU812 cells.

The secretion of TNF- $\alpha$ from basophils stimulated with untreated $\beta$-LG was $242.4 \mathrm{pg} / \mathrm{mL}$ and that induced by I $\beta$-LG, U-I $\beta$-LG, and I-U $\beta$-LG decreased to $141.1(P<0.05), 155.0(P<0.05)$, and $161.7(P<$ $0.05) \mathrm{pg} / \mathrm{mL}$, respectively. The difference in expression induced by the 3 treated $\beta$-LG was also significant (Figure 5C; $P<0.05)$. Therefore, irradiation of $\beta-\mathrm{LG}$, with or without ultrasound treatment can reduce secretion of TNF- $\alpha$ from $\beta$-LG-treated human KU812 cells.

Interleukin-6 can enhance immune responses through the induction of other inflammatory mediators in KU812 cells and its production is related to the activation of NF- $\kappa B$ (Azzolina et al., 2003). The secretion of IL-6 by KU812 cells stimulated with untreated $\beta-L G$ was $645.5 \mathrm{pg} / \mathrm{mL}$ and that induced by I $\beta-\mathrm{LG}$, U-I $\beta$-LG, and I-U $\beta$-LG decreased to $352.0,381.3$, and $384.3 \mathrm{pg} /$ $\mathrm{mL}$ (Figure 5D; $P<0.05$ ), respectively. The secretion of all 4 inflammatory mediators from KU812 cells was reduced the most by stimulating with irradiated $\beta-\mathrm{LG}$, and slightly higher in U-I BLG and I-U BLG.

\section{Detection of Intracellular $\mathrm{Ca}^{2+}$ Content}

The increase in intracellular $\mathrm{Ca}^{2+}$ levels and activation of protein kinase $\mathrm{C}$ are key steps in KU812

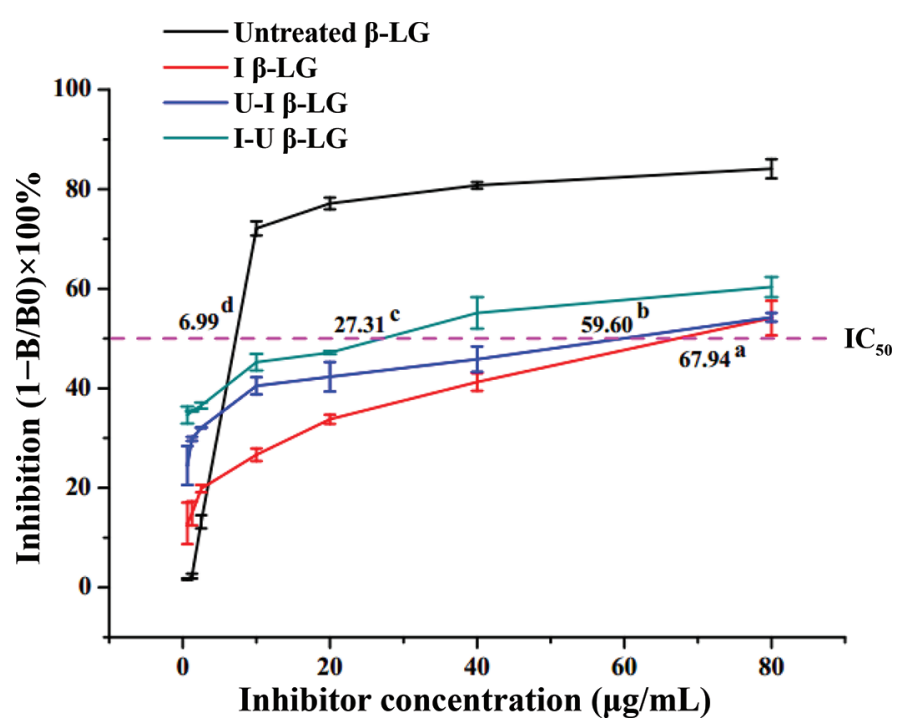

Figure 4. The $\operatorname{IgE}$ binding capacity of $\beta$-LG untreated, irradiation-treated, ultrasound-treated, or a combination was measured by indirect competitive ELISA. Data values are shown as the mean and SE $(\mathrm{n}=3)$, and means with different letters were significantly different from untreated $\beta$-LG $(P<0.05) . \mathrm{IC}_{50}=$ half-maximal inhibitory concentration. I $\beta$-LG $=$ irradiated $\beta$-LG; U-I $\beta$-LG $=\beta$-LG sonicated then irradiated; $\mathrm{I}-\mathrm{U} \beta-\mathrm{LG}=\beta-\mathrm{LG}$ irradiated then sonicated. $\mathrm{B} 0=$ optical density value of untreated $\beta-\mathrm{LG} ; \mathrm{B}=$ optical density value of $\beta-L G$ treated by irradiation or irradiation combined with ultrasound. degranulation and the movement of calcium can also regulate histamine release. To characterize the $\mathrm{Ca}^{2+}$ levels in sensitized KU812 cells induced by $\beta-L G$, the fluorescence intensity of the complex formed by $\mathrm{Ca}^{2+}$ and the fluorescent probe 3-AM was imaged (Figure $6)$. The green fluorescence in cells exposed to untreated $\beta-\mathrm{LG}$ was markedly brighter than that of the processed $\beta-\mathrm{LG}$, indicating that the intracellular $\mathrm{Ca}^{2+}$ level in untreated $\beta-\mathrm{LG}$ was the highest of the 4. Therefore, irradiation and ultrasound treatment could inhibit the $\beta$-LG-induced influx of $\mathrm{Ca}^{2+}$ and alleviate the IgEmediated allergic reaction.

\section{DISCUSSION}

In this study, we explored the effect of irradiation, with or without ultrasound, on changes in $\beta-\mathrm{LG}$ structure and related changes in IgE-mediated immune responses. Irradiation is a widely accepted food-processing method, which is used for sterilization and to prolong shelf-life of food, with minimal adverse effects on the sensory and nutritional qualities at medium irradiation doses (1-10 kGy; Otte, 1997; Diehl, 2002). Native $\beta$-LG irradiated with doses up to $10 \mathrm{kGy}$ undergoes some structural modification (Oliveira et al., 2007). However, higher irradiation doses $(\geq 10 \mathrm{kGy})$ result in the development of off-flavors and loss of nutritional quality of milk (Alvarez and Ji, 2003). High-intensity ultrasound with a frequency range of 16 to $100 \mathrm{kHz}$ and a power range of 10 to $100 \mathrm{~W} / \mathrm{cm}^{2}$ are common in the food industry, for applications such as the improvement of foaming, emulsifying, and gelation properties of protein (Arzeni et al., 2012). Hence, we investigated whether ultrasound at a frequency of $28 \mathrm{kHz}$ and power of 300 $\mathrm{W} / \mathrm{cm}^{2}$ could assist irradiation with $5 \mathrm{kGy}$ to change the structure and potential allergenicity of $\beta$-LG.

Gamma radiation with or without ultrasound resulted in the formation of soluble aggregates of $\beta$-LG, with much higher molecular weights. This is consistent with a previous report that $\beta$-LG polymers appeared after irradiation at doses up to 5 kGy (Oliveira et al., 2007). Analysis by CD, intrinsic fluorescence, and ANS-fluorescence spectra revealed that more ordered secondary structures (with more $\alpha$-helix and $\beta$-sheet) and more aggregates were formed after all 3 treatments. The content of disordered structure and surfaceexposure of hydrophobic and aromatic AA side-chains increased in U-I and I-U $\beta$-LG compared with I $\beta$-LG. Two mechanisms are possible for the formation of these aggregates. One is the adhesion of exposed hydrophobic regions to form stable noncovalent aggregates (Iametti et al., 1998), and the other is the formation of intermolecular disulfide bonds, which appears unlikely to have occurred in this study, because the total free thiol 
content was increased in all the processed $\beta$-LG. Arzeni et al. (2012) also found that the hydrophobicity of ovalbumin was increased by ultrasound treatment at 20 $\mathrm{kHz}$, and similarly, hydrophobic groups in reconstituted milk protein could be exposed by ultrasound treatment at $12.5 \mathrm{~W}$ (Sun et al., 2014).

The observed intrinsic fluorescence intensity, which mainly arises from the tryptophan-19 (Trp19) residue (Creamer, 1995), of processed $\beta$-LG was lower than that of untreated $\beta$-LG, although $\beta$-LG contains 2 Trp residues, Trp16 and Trp19 (Kehoe et al., 2008). Because Trp16 is close to the Cys66-Cys160 disulfide bond, the intrinsic fluorescence of Trp16 can be quenched in aque- ous solution (Manderson et al., 1998). When Trp19 is located in a nonpolar environment, it would be in close proximity to the Arg124 residue, which is an efficient fluorescence quencher (Prabakaran and Damodaran, 1997). Therefore, the decreased fluorescence intensity suggested that the Trp19 residue was closer to Arg124, indicating that the structure of the processed $\beta-\mathrm{LG}$ was more compact. The intrinsic fluorescence red shifts also suggested that Trp residues moved from a polar environment to a less polar one because of the decreased exposure of Trp and Tyr residues to the solvent (Lakowicz, 2006). Moreover, the increased free thiol content in the processed $\beta-\mathrm{LG}$ and the contents in the U-I
A

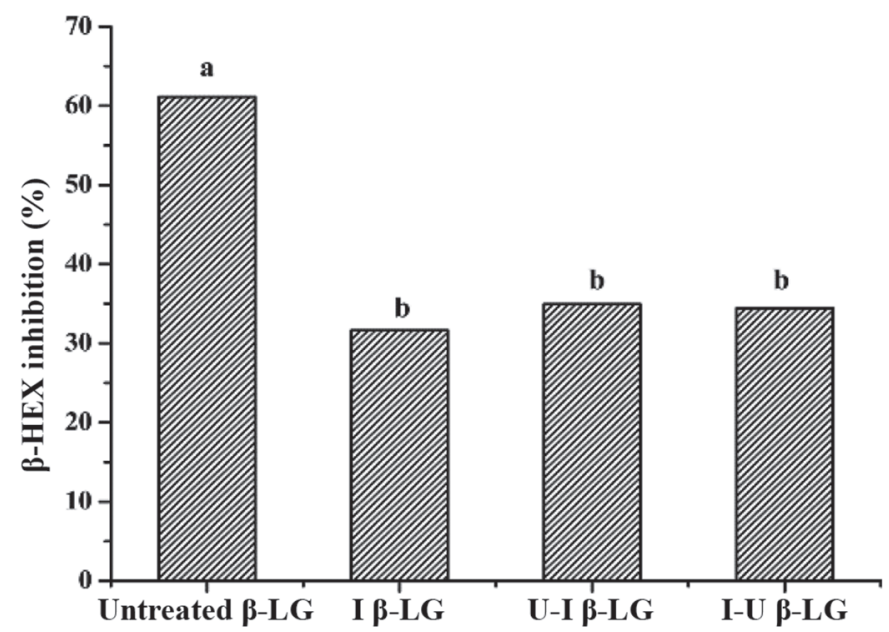

C

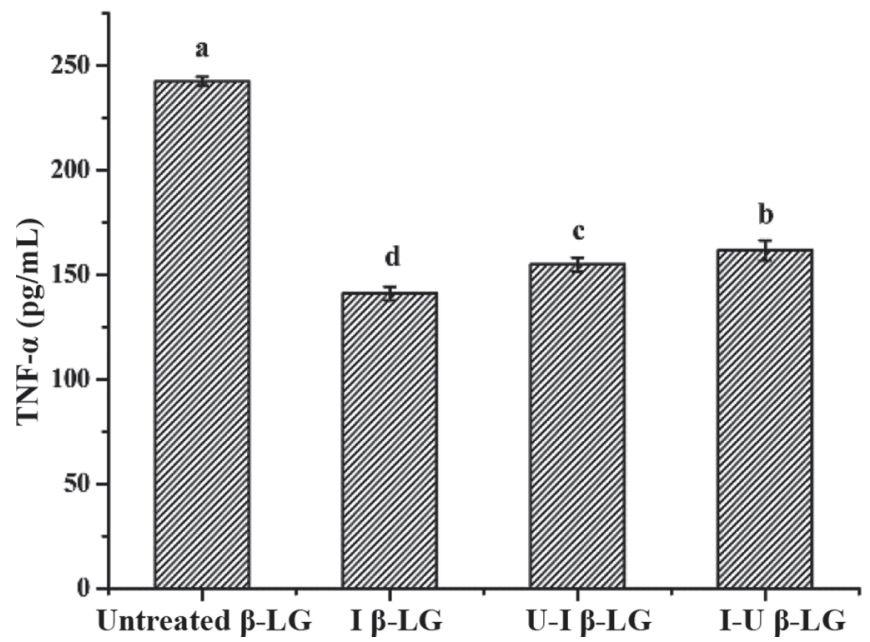

B

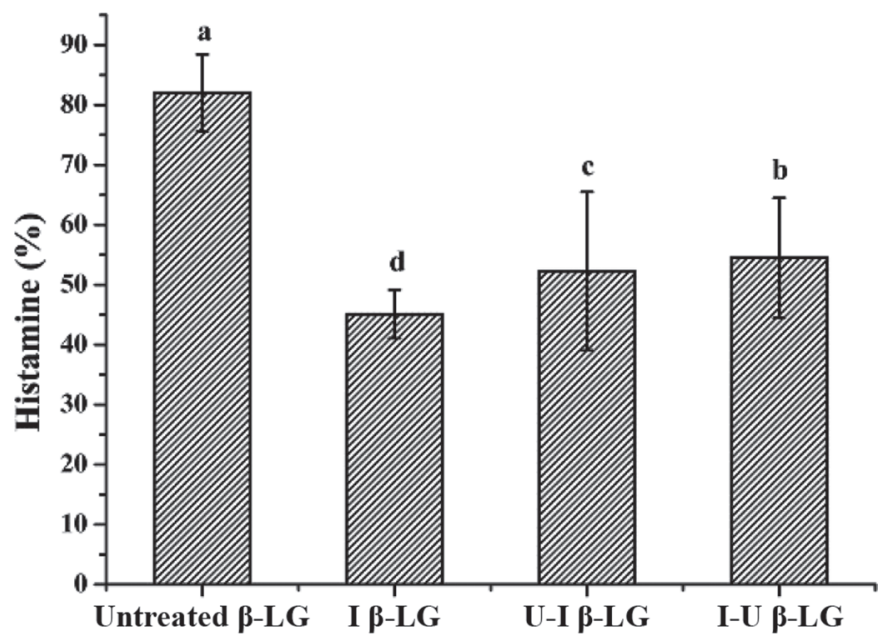

D

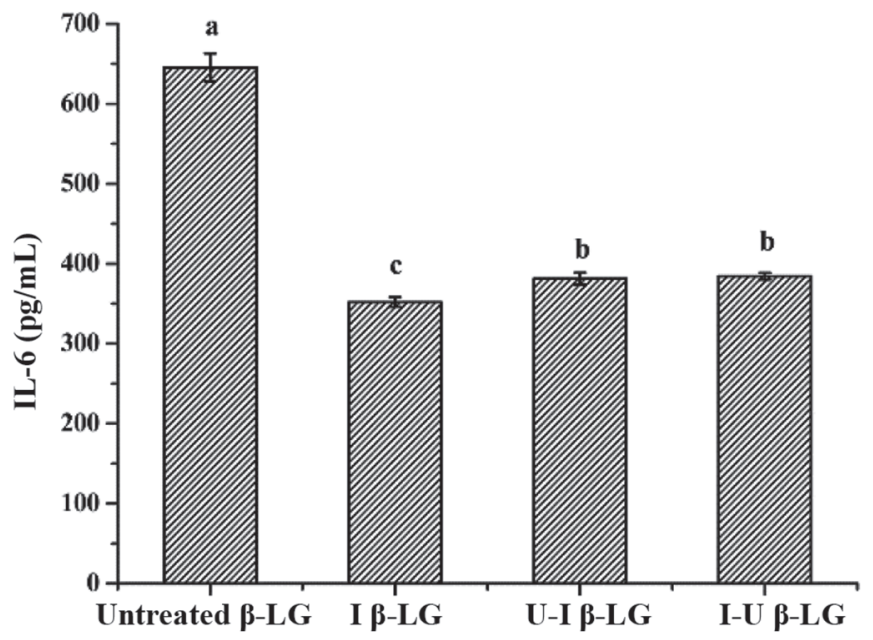

Figure 5. $\beta$-Hexosaminidase ( $\beta$-HEX; A), histamine (B), tumor necrosis factor (TNF)- $\alpha$ (C), and IL-6 (D) released from KU812 cells stimulated with treated $\beta$-LG were tested by ELISA kits (Abcam, Cambridge, MA). Different letters in the same graph indicate a significant difference $(P<0.05)$. The same letter indicates no significant difference $(P>0.05)$. I $\beta$-LG $=$ irradiated $\beta$-LG; U-I $\beta$-LG $=\beta$-LG sonicated then irradiated; $\mathrm{I}-\mathrm{U} \beta-\mathrm{LG}=\beta$-LG irradiated then sonicated. Data are presented as the mean $\pm \mathrm{SD}$. 
$\beta-\mathrm{LG}$ and I-U $\beta$-LG being higher than that of I $\beta$-LG suggested that the disulfide bonds of Cys106-Cys119 and Cys66-Cys160 were broken in the U-I $\beta-L G$ and I-U $\beta$-LG, but that the Cys66-Cys160 disulfide bond remained stable during irradiation.

Some aggregation was observed in purified $\beta-\mathrm{LG}$, which could be explained by interactions with the acetonitrile in the HPLC eluent used (Chen et al., 2007; Dhamole et al., 2010). Acetonitrile can induce structural changes in the $\beta-\mathrm{LG}$ genetic variants, $\mathrm{A}$ and $\mathrm{B}$ at $\mathrm{pH} 7$, such as aggregation and unfolding (Naqvi et al., 2013). In our CD spectra, the content of $\beta$-sheet was lowest in untreated $\beta$-LG. The native variants $\mathrm{A}$ and $\mathrm{B}$ of $\beta$-LG, with a predominantly $\beta$-sheet structure, showed an intense negative band at $216 \mathrm{~nm}$ (Dong et al., 1996). As the acetonitrile concentration was increased, the CD spectral signature was noticeably transformed from $\beta$-sheet to typical $\alpha$-helix structure (Naqvi et al., 2013).

Treatment with irradiation and ultrasound can structurally alter both sequential and conformational epitopes, which can further affect potential allergenicity (Fukase et al., 1994; Byun et al., 2000). In this study, $\mathrm{IgE}$ binding capacity was significantly decreased in all the treated $\beta-\mathrm{LG}$, especially for U-I $\beta-\mathrm{LG}$ and I $\beta$-LG. The extent of aggregation of the irradiated $\beta-L G$ was the highest of the 3 treated $\beta-\mathrm{LG}$, whereas ultrasound treatment created a looser structure by disrupting the Cys66-Cys160 disulfide bond and exposing hydrophobic groups, resulting in exposure of more epitopes in

A

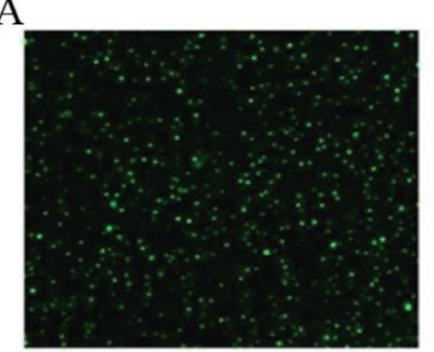

$\mathrm{C}$

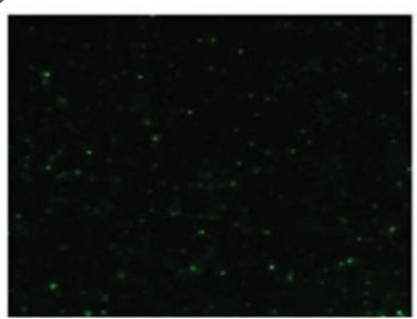

Figure 6. Change of intracellular $\mathrm{Ca}^{2+}$ released in IgE-activated KU812 cells stimulated by $\beta$-LG; the intensity of the green fluorescent spots indicates the $\mathrm{Ca}^{2+}$ concentration. (A) Untreated $\beta-\mathrm{LG},(\mathrm{B}) \mathrm{ir}-$ radiated $\beta-\mathrm{LG}$, (C) $\beta-\mathrm{LG}$ sonicated then irradiated, and (D) $\beta-\mathrm{LG}$ irradiated then sonicated.
I-U $\beta$-LG than U-I $\beta$-LG. Moreover, a previous study showed that aggregates of $\beta-\mathrm{LG}$ were formed and its IgE binding ability was decreased when gamma irradiation was performed at doses of 3,5 , and $10 \mathrm{kGy}$ (Lee et al., 2001). The allergenicity of $\beta$-LG was not noticeably altered by ultrasound treatment at $20 \mathrm{kHz}$, although it exposed more hydrophobic regions (Stanic-Vucinic et al., 2012). These studies suggested that partial burial of conformational $\beta$-LG epitopes could be induced by irradiation, but some of these epitopes may be reexposed by ultrasound.

Immunoglobulin $\mathrm{E}$ acts by regulating the protein cross-linked IgE/Fc $\varepsilon$ RI-receptor complexes, which initiate degranulation of mast cells and basophils and release of bio-activators, in IgE-mediated type I allergic reactions (Knol, 2006; Gould and Sutton, 2008). Activation and degranulation of KU812 cells can also release chemotactic cytokines such as TNF- $\alpha$ and IL-6, which in turn, can elicit an inflammatory response and regulate the downstream signaling pathway (Theoharides and Kalogeromitros, 2006). All the treated $\beta$-LG, especially irradiation-treated $\beta$-LG, markedly reduced secretion of $\beta$-HEX, histamine, TNF- $\alpha$, and IL- 6 by KU812 cells. Histamine and TNF- $\alpha$ were lower in U-I $\beta$-LG than I-U $\beta$-LG, which agreed with the observed change in $\operatorname{Ig} E$ binding capacity. In addition, the influx of $\mathrm{Ca}^{2+}$ was accompanied by the release of histamine (Wernersson and Pejler, 2014). The intracellular $\mathrm{Ca}^{2+}$ concentration was reduced significantly, when KU812 cells were stimulated by all the treated $\beta-\mathrm{LG}$, compared with stimulation by untreated $\beta$-LG.

\section{CONCLUSIONS}

Irradiation treatment induced a stable aggregate structure in $\beta$-LG and decreased its IgE binding capacity. Ultrasound treatment was more effective in reducing $\beta$-LG allergenicity, when used before irradiation than after irradiation, because irradiation followed by ultrasound appeared to expose more IgE binding epitopes than ultrasound before irradiation. The stimulation of cytokine secretion by KU812 cells declined markedly with all treated $\beta$-LG, the biggest decline being with irradiated $\beta$-LG. As with IgE binding, ultrasound was more effective if used before irradiation, than after. In summary, irradiation with or without sonication markedly reduced the allergenicity of $\beta$-LG by changing its secondary structure and ultrasound was more effective when used before irradiation. Further research is needed to find out whether these in vitro results translate to the in vivo situation. If they do, ultrasound before irradiation may have potential as a food processing technology to reduce the allergenic properties of milk proteins. 


\section{ACKNOWLEDGMENTS}

The work was supported by National Key R\&D Program of China (2018YFC1604205), National Natural Science Foundation of China (No. 31760431), Outstanding Youth Funding Scheme from Jiangxi Province (No. 20162BCB23016), the Research Program of State Key Laboratory of Food Science and Technology (No. SKLF-ZZB-201712 and SKLF-ZZA-201612). The authors have not stated any conflicts of interest.

\section{REFERENCES}

Alvarez, V. B., and T. Ji. 2003. Emerging processing and preservation technologies for milk and dairy products. Page 313-327 in Food Science and Food Biotechnology. G. F. Gutierrez-López and G. V. Barbosa-Cánovas, ed. CRC Press, London, UK.

Arzeni, C., O. E. Perez, and A. M. R. Pilosof. 2012. Functionality of egg white proteins as affected by high intensity ultrasound. Food Hydrocoll. 29:308-316. https://doi.org/10.1016/j.foodhyd.2012.03 .009 .

Azzolina, A., A. Bongiovanni, and N. Lampiasi. 2003. Substance P induces TNF- $\alpha$ and IL-6 production through NF- $\kappa \mathrm{B}$ in peritoneal mast cells. Biochim. Biophys. Acta 1643:75-83. https://doi.org/10 .1016/j.bbamcr.2003.09.003.

Bonfatti, V., L. Grigoletto, A. Cecchinato, L. Gallo, and P. Carnier. 2008. Validation of a new reversed-phase high-performance liquid chromatography method for separation and quantification of bovine milk protein genetic variants. J. Chromatogr. A 1195:101106. https://doi.org/10.1016/j.chroma.2008.04.075.

Bramaud, C., P. Aimar, and G. Daufin. 1997. Whey protein fractionation: Isoelectric precipitation of alpha-lactalbumin under gentle heat treatment. Biotechnol. Bioeng. 56:391-397. https: //doi.org/10.1002/(SICI)1097-0290(19971120)56:4<391::AIDBIT5 > 3.0.CO;2-J.

Byun, M. W., J. Kim, J. W. Lee, J. W. Park, C. S. Hong, and I. J. Kang. 2000. Effects of gamma radiation on the conformational and antigenic properties of a heat-stable major allergen in brown shrimp. J. Food Prot. 63:940-944. https://doi.org/10.4315/0362 $-028 \mathrm{X}-63.7 .940$.

Byun, M. W., J. W. Lee, H. S. Yook, C. Jo, and H. Y. Kim. 2002. Application of gamma irradiation for inhibition of food allergy. Radiat. Phys. Chem. 63:369-370. https://doi.org/10.1016/S0969 $-806 \mathrm{X}(01) 00528-\mathrm{X}$.

Chen, Y. X., C. T. Mant, and R. S. Hodges. 2007. Preparative reversed-phase high-performance liquid chromatography collection efficiency for an antimicrobial peptide on columns of varying diameters (1 mm to $9.4 \mathrm{~mm}$ ID). J. Chromatogr. A 1140:112-120. https://doi.org/10.1016/j.chroma.2006.11.052.

Creamer, L. K. 1995. Effect of sodium dodecyl sulfate and palmitic acid on the equilibrium unfolding of bovine beta-lactoglobulin. Biochemistry 34:7170-7176. https://doi.org/10.1021/bi00021a031.

Dhamole, P. B., P. Mahajan, and H. Feng. 2010. Sugaring out: A new method for removal of acetonitrile from preparative RP-HPLC eluent for protein purification. Process Biochem. 45:1672-1676. https: //doi.org/10.1016/j.procbio.2010.06.020.

Diehl, J. F. 2002. Food irradiation - Past, present and future. Radiat. Phys. Chem. 63:211-215. https://doi.org/10.1016/S0969 -806X(01)00622-3.

Dong, A., J. Matsuura, S. D. Allison, E. Chrisman, M. C. Manning, and J. F. Carpenter. 1996. Infrared and circular dichroism spectroscopic characterization of structural differences between betalactoglobulin A and B. Biochemistry 35:1450-1457. https://doi .org/10.1021/bi9518104.

Fiocchi, A., H. J. Schunemann, J. Brozek, P. Restani, K. Beyer, R. Troncone, A. Martelli, L. Terracciano, S. L. Bahna, F. Rance, M. Ebisawa, R. G. Heine, A. Assa'ad, H. Sampson, E. Verduci, G. R. Bouygue, C. Baena-Cagnani, W. Canonica, and R. F. Lockey.
2010. Diagnosis and rationale for action against cow's milk allergy (DRACMA): A summary report. J. Allergy Clin. Immunol. 126:1119-1128. https://doi.org/10.1016/j.jaci.2010.10.011.

Fujimura, Y., H. Tachibana, M. Maeda-Yamamoto, T. Miyase, M. Sano, and K. Yamada. 2002. Antiallergic tea catechin, (-)-epigallocatechin-3-O-(3-O-methyl)-gallate, suppresses FcERI expression in human basophilic KU812 cells. J. Agric. Food Chem. 50:57295734. https://doi.org/10.1021/jf025680z.

Fukase, H., E. Ohdaira, N. Masuzawa, and M. Ide. 1994. Effect of ultrasound in soybean protein extraction. Jpn. J. Appl. Phys. 33(Part 1, No. 5B):3088-3090. https://doi.org/10.1143/JJAP.33 .3088 .

Gesan-Guiziou, G., G. Daufin, M. Timmer, D. Allersma, and C. Van der Horst. 1999. Process steps for the preparation of purified fractions of alpha-lactalbumin and beta-lactoglobulin from whey protein concentrates. J. Dairy Res. 66:225-236. https://doi.org/10 .1017/S0022029999003519.

Gould, H. J., and B. J. Sutton. 2008. IgE in allergy and asthma today. Nat. Rev. Immunol. 8:205-217. https://doi.org/10.1038/nri2273.

Host, A. 2002. Frequency of cow's milk allergy in childhood. Ann. Allergy Asthma Immunol. 89:33-37. https://doi.org/10.1016/S1081 $-1206(10) 62120-5$

Iametti, S., L. Scaglioni, S. Mazzini, G. Vecchio, and F. Bonomi. 1998. Structural features and reversible association of different quaternary structures of beta-lactoglobulin. J. Agric. Food Chem. 46:2159-2166. https://doi.org/10.1021/jf980004b.

Kehoe, J. J., G. E. Remondetto, M. Subirade, E. R. Morris, and A. Brodkorb. 2008. Tryptophan-mediated denaturation of $\beta$-lactoglobulin A by UV irradiation. J. Agric. Food Chem. 56:4720-4725. https:/ /doi.org/10.1021/jf0733158.

Knipping, K., B. C. van Esch, A. G. van Ieperen-van Dijk, E. van Hoffen, T. van Baalen, L. M. Knippels, S. van der Heide, A. E. Dubois, J. Garssen, and E. F. Knol. 2012. Enzymatic treatment of whey proteins in cow's milk results in differential inhibition of IgE-mediated mast cell activation compared to T-cell activation. Int. Arch. Allergy Immunol. 159:263-270. https://doi.org/10 $.1159 / 000338007$.

Knol, E. F. 2006. Requirements for effective IgE cross-linking on mast cells and basophils. Mol. Nutr. Food Res. 50:620-624. https://doi .org/10.1002/mnfr.200500272.

Kuan, Y.-H., R. Bhat, A. Patras, and A. A. Karim. 2013. Radiation processing of food proteins - A review on the recent developments. Trends Food Sci. Technol. 30:105-120. https://doi.org/10.1016/j .tifs. 2012.12.002.

Kuo, C. J., and W. J. Harper. 2003. Rennet gel properties of milk protein concentrates (MPC). Milchwissenschaft 58:181-184.

Lakowicz, J. R. 2006. Protein fluorescence. Page 530-573 in Principles of Fluorescence Spectroscopy. 3th ed. Springer Science \& Business Media, New York, NY.

Lee, J. W., J. H. Kim, H. S. Yook, K. O. Kang, S. Y. Lee, H. J. Hwang, and M. W. Byun. 2001. Effects of gamma radiation on the allergenic and antigenic properties of milk proteins. J. Food Prot. 64:272-276. https://doi.org/10.4315/0362-028x-64.2.272.

Li, X., Z. L. Luo, H. B. Chen, and Y. S. Cao. 2008. Isolation and antigenicity evaluation of beta-lactoglobulin from buffalo milk. Afr. J. Biotechnol. 7:2258-2264. https://doi.org/10.1016/j.jbiotec.2008 .07 .1723

Macdonald, L. E., J. Brett, D. Kelton, S. E. Majowicz, K. Snedeker, and J. M. Sargeant. 2011. A systematic review and meta-analysis of the effects of pasteurization on milk vitamins, and evidence for raw milk consumption and other health-related outcomes. J. Food Prot. 74:1814-1832. https://doi.org/10.4315/0362-028X.JFP $-10-269$.

Manderson, G., M. Hardman, and L. Creamer. 1998. Effect of heat treatment on the conformation and aggregation of $\beta$-lactoglobulin A, B, and C. J. Agric. Food Chem. 46:5052-5061. https://doi.org/ $10.1021 /$ jf980515y.

Meng, X., Y. Bai, J. Gao, X. Li, and H. Chen. 2017. Effects of high hydrostatic pressure on the structure and potential allergenicity of the major allergen bovine beta-lactoglobulin. Food Chem. 219:290-296. https://doi.org/10.1016/j.foodchem.2016.09.153. 
Meng, X., X. Li, X. Wang, J. Gao, H. Yang, and H. Chen. 2016. Potential allergenicity response to structural modification of irradiated bovine alpha-lactalbumin. Food Funct. 7:3102-3110. https://doi .org/10.1039/C6FO00400H.

Muresan, S., A. van der Bent, and F. A. de Wolf. 2001. Interaction of $\beta$-lactoglobulin with small hydrophobic ligands as monitored by fluorometry and equilibrium dialysis: Nonlinear quenching effects related to protein-protein association. J. Agric. Food Chem. 49:2609-2618. https://doi.org/10.1021/jf0012188.

Naqvi, Z., E. Ahmad, R. H. Khan, and M. Saleemuddin. 2013. Nonnative states of bovine beta-lactoglobulin induced by acetonitrile: $\mathrm{pH}$-dependent unfolding of the two genetic variants A and B. Cell Biochem. Biophys. 66:175-185. https://doi.org/10.1007/s12013 -012-9466-7.

Oliveira, C. L., L. de la Hoz, J. C. Silva, I. L. Torriani, and F. M. Netto. 2007. Effects of gamma radiation on beta-lactoglobulin: Oligomerization and aggregation. Biopolymers 85:284-294. https:/ /doi.org/10.1002/bip.20610.

Otte, S. 1997. Irradiation enhances food quality and safety. Healthc. Foodserv. 7:5-8.

Prabakaran, S., and S. Damodaran. 1997. Thermal unfolding of B-lactoglobulin: Characterization of initial unfolding events responsible for heat-induced aggregation. J. Agric. Food Chem. 45:4303-4308. https://doi.org/10.1021/Jf970269a.

Rahaman, T., T. Vasiljevic, and L. Ramchandran. 2016. Effect of processing on conformational changes of food proteins related to allergenicity. Trends Food Sci. Technol. 49:24-34. https://doi.org/ 10.1016/j.tifs.2016.01.001.

Santos, M. J., J. A. Teixeira, and L. R. Rodrigues. 2012. Fractionation of the major whey proteins and isolation of $\beta$-Lactoglobulin variants by anion exchange chromatography. Separ. Purif. Tech. 90:133-139. https://doi.org/10.1016/j.seppur.2012.02.030.

Shi, L., H. Xu, Y. Wu, X. Li, L. Zou, J. Gao, and H. Chen. 2017. Alpha7-nicotinic acetylcholine receptors involve the imidaclopridinduced inhibition of IgE-mediated rat and human mast cell activation. RSC Advances 7:51896-51906. https://doi.org/10.1039/ C7RA07862E.

Stanic, D., E. Monogioudi, E. Dilek, J. Radosavljevic, M. AtanaskovicMarkovic, O. Vuckovic, L. Raija, M. Mattinen, J. Buchert, and
T. Cirkovic Velickovic. 2010. Digestibility and allergenicity assessment of enzymatically cross-linked beta-casein. Mol. Nutr. Food Res. 54:1273-1284. https://doi.org/10.1002/mnfr.200900184.

Stanic-Vucinic, D., M. Stojadinovic, M. Atanaskovic-Markovic, J. Ognjenovic, H. Gronlund, M. van Hage, R. Lantto, A. I. Sancho, and T. C. Velickovic. 2012. Structural changes and allergenic properties of beta-lactoglobulin upon exposure to high-intensity ultrasound. Mol. Nutr. Food Res. 56:1894-1905. https://doi.org/ $10.1002 /$ mnfr.201200179.

Sun, Y. J., J. H. Chen, S. W. Zhang, H. J. Li, J. Lu, L. Liu, H. Uluko, Y. L. Su, W. M. Cui, W. P. Ge, and J. P. Lv. 2014. Effect of power ultrasound pre-treatment on the physical and functional properties of reconstituted milk protein concentrate. J. Food Eng. 124:11-18. https://doi.org/10.1016/j.jfoodeng.2013.09.013.

Teodorowicz, M., J. van Neerven, and H. Savelkoul. 2017. Food processing: The influence of the Maillard reaction on immunogenicity and allergenicity of food proteins. Nutrients 9:835. https://doi .org/10.3390/nu9080835.

Theoharides, T. C., and D. Kalogeromitros. 2006. The critical role of mast cells in allergy and inflammation. Ann. N. Y. Acad. Sci. 1088:78-99. https://doi.org/10.1196/annals.1366.025.

Thomas, K., C. Herouet-Guicheney, G. Ladics, G. Bannon, A. Cockburn, R. Crevel, J. Fitzpatrick, C. Mills, L. Privalle, and S. Vieths. 2007. Evaluating the effect of food processing on the potential human allergenicity of novel proteins: International workshop report. Food Chem. Toxicol. 45:1116-1122. https://doi.org/10.1016/j.fct .2006.12.016.

Villamiel, M., and P. de Jong. 2000. Influence of high-intensity ultrasound and heat treatment in continuous flow on fat, proteins, and native enzymes of milk. J. Agric. Food Chem. 48:3068. https://doi .org/10.1021/jf0006224.

Villamiel, M., E. Van Hamersveld, and P. De Jong. 1999. Effect of ultrasound processing on the quality of dairy products. Milchwissenschaft 54:69-73.

Wernersson, S., and G. Pejler. 2014. Mast cell secretory granules: Armed for battle. Nat. Rev. Immunol. 14:478-494. https://doi .org/10.1038/nri3690.

Wittig, I., H. P. Braun, and H. Schagger. 2006. Blue native PAGE. Nat. Protoc. 1:418-428. https://doi.org/10.1038/nprot.2006.62. 